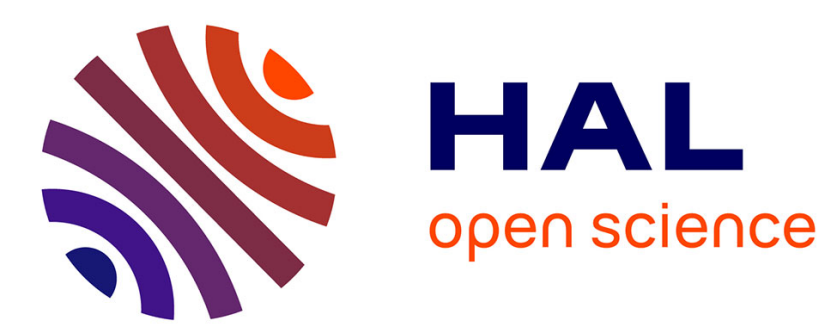

\title{
Rethinking ignorance production in the field of reproductive biomedicine: An introduction
}

Sezin Topçu, Irene Maffi

\section{To cite this version:}

Sezin Topçu, Irene Maffi. Rethinking ignorance production in the field of reproductive biomedicine: An introduction. Reproductive Biomedicine \& Society Online, In press, 10.1016/j.rbms.2021.12.002 . hal-03514776

\author{
HAL Id: hal-03514776 \\ https://hal.science/hal-03514776
}

Submitted on 6 Jan 2022

HAL is a multi-disciplinary open access archive for the deposit and dissemination of scientific research documents, whether they are published or not. The documents may come from teaching and research institutions in France or abroad, or from public or private research centers.
L'archive ouverte pluridisciplinaire HAL, est destinée au dépôt et à la diffusion de documents scientifiques de niveau recherche, publiés ou non, émanant des établissements d'enseignement et de recherche français ou étrangers, des laboratoires publics ou privés. 

Oreskes and Conway, 2010 N. Oreskes, E.M. Conway

Merchants of Doubt. How a Handful of Scientists Obscured the Truth on Issues from Tobacco Smoke to Global Warming Bloomsbury Press, NY, Berlin and London (2010) Google Scholar

Oudshoorn, 2003 N. Oudshoorn

Male Pill. A Biography of a Technology in the Making

Duke University Press, Durham and London (2003)

Google Scholar

Owens, 2017 K. Owens

Too much of a good thing? American childbirth, intentional ignorance, and the boundaries of responsible knowledge

Science Technology and Human Values, 42 (5) (2017), pp. 848-871

[ $]$ View PDF CrossRef View Record in Scopus Google Scholar

Perrenoud, 2014 P. Perrenoud

Naissance et évolution des pratiques: entre evidence-based, expérience et intuition

C. Burton-Jeangros, R. Hammer, I. Maffi (Eds.), Accompagner la naissance, BNS Press, Lausanne and Bangkok, Terrains socio-anthropologiques en Suisse romande (2014), pp. 133-154

$[7$ View PDF CrossRef Google Scholar

Perrow, 1999 C. Perrow

Normal Accidents

Princeton University Press, Princeton, Living with High-Risk Technologies (1999)

Google Scholar

Popper, 2002 K. Popper

The Logic of Scientific Discovery

Routledge, London (2002)

Google Scholar

Proctor and Schiebinger, 2008 R.N. Proctor, L. Schiebinger

Agnotology

Stanford University Press, Stanford, The Making and Unmaking of

Ignorance (2008)

Google Scholar

Proctor, 2011 R.N. Proctor

Golden Holocaust

The University of California Press, Berkeley, LA and London, Origins of the Cigarette Catastrophe and the Case for Abolition (2011)

Google Scholar

Rapp, 1998 R. Rapp

Refusing Prenatal Diagnosis : The Meanings of Bioscience in a

Multicultural World

Science, Technology \& Human Values, 23 (1) (1998), pp. $45-70$

$\square$ View PDF CrossRef View Record in Scopus Google Scholar

Rayner, 2012 S. Rayner

Unconfortable knowledge: the social construction of ignorance in science

and environmental policy discourse

Economy and Society, 41 (1) (2012), pp. 107-125

[7 View PDF CrossRef View Record in Scopus Google Scholar

Sarda, 2011 G. Sarda

Artificially maintained scientific controversies, the construction of

maternal choice and caesarean section rates

Social Theory \& Health, 9 (2) (2011), pp. 166-182

View PDF CrossRef View Record in Scopus Google Scholar

Serres, 1995 M. Serres

The Natural Contract

The University of Michigan Press, Ann Arbor (1995)

Google Scholar

Strathern, 1992 M. Strathern

After Nature: English Kinship in the Late Twentieth Century

Cambridge University Press, Cambridge (1992)

Google Scholar

Topçu, 2019 S. Topçu

Caesarean or Vaginarean Epidemics? Techno-birth, risk and obstetric

practice in Turkey

Health, Risk \& Society, 21 (3-4) (2019), pp. 141-163

I View PDF CrossRef View Record in Scopus Google Scholar

Tuana, 2004 N. Tuana

Coming to understand orgasm and the epistemology of ignorance

Hypatia, 19 (1) (2004), pp. 193-232

Google Scholar

Van Kammen and Oudshoorn, 2002 J. Van Kammen, N. Oudshoorn

Gender \& risk assessment in contraceptive technology

Sociology of Health and Illness, 24 (4) (2002), pp. 436-461

View PDF View Record in Scopus Google Scholar

Wagner, 2006 M. Wagner

Born in the USA: How a Broken Maternity System Must be Fixed to Put

Women and Children First

University of California Press, Berkeley and Los Angeles (2006)

Google Scholar

Wehling, 2015 Wehling, P., 2015. Fighting a losing battle? The right not to know and the dynamics of biomedical knowledge production. In Gross, M., McGoey, L. (Eds.), 2015. Routledge International Handbook of Ignorance Studies. Routledge, London and New York, pp. 206-214.

Google Scholar 